\title{
Solid bio-fuel production at Moscow wastewater treatment plant
}

\author{
Nikolay Makisha, ${ }^{1, *}$, Igor Gulshin ${ }^{1}$ \\ Moscow State University of Civil Engineering, 26, Yaroslavskoye shosse, Moscow, Russia, 129337
}

\begin{abstract}
The article has an aim to describe experience of Moscow in the field of solid bio-fuel production at wastewater treatment plants (WWTP). Brief assessment of solid biofuel production technology at biological treatment facilities of domestic and mixed sewage (wastewater sludge as a fuel resource) shows its significant potential from the economic, environmental and social points of view that will ensure the sustainable development of the area (cities, regions) of application. Solid biofuel production is a technological stage of sludge treatment at wastewater treatment plants aimed at reducing the sludge mass and changing their physical and mechanical properties for its further use at as a fuel component on condensing and thermal power plants or as alternative fuel for cement production and energy supplements for burning of solid domestic waste. The technology of solid biofuel production is based on removing moisture of wastewater sludge in drying machines. The solid fuel facilities capacity lies in the range of 1 to 130 tons per day, when the entire amount sludge is exposed to drying (effluent humidity of sludge is $10 \%$ ), or 1 to 400 tons per day when the sludge is partially dried and afterwards is mixed with the initial sludge (effluent humidity of sludge is $40 \%$ ).
\end{abstract}

\section{Introduction}

The use of up-to-date thermal technologies allows minimizing changes in emission of gases appeared because of sludge drying, and that does not lead to excess of normative indicators in the exhaust air. At the same time, heat energy hidden in the dry matter of the sludge is used to cover the energy necessary for the evaporation of excess moisture and heating the combustion air. This also helps to make the sludge volume 3 times lower, and to use the energy potential of dried sludge as a fuel component on condensing and thermal power plants, or as alternative fuel for cement production and energy supplements for burning of solid domestic waste [1,2].

Brief assessment of solid biofuel production technology at biological treatment facilities of domestic and mixed sewage (wastewater sludge as a fuel resource) shows its significant potential from the economic, environmental and social points of view that will ensure the sustainable development of the area (cities, regions) of application. In this regard, the sludge

* Corresponding author - makishana@mgsu.ru 
storage on sludge sites as well as the neutralization of sediments may be considered as extremely unfavorable and impractical [3].

\section{Materials and methods}

Solid biofuel production is a technological stage of sludge treatment at wastewater treatment plants aimed at reducing the sludge mass and changing their physical and mechanical properties for its further use at as a fuel component on condensing and thermal power plants or as alternative fuel for cement production and energy supplements for burning of solid domestic waste [4,5]. The use of solid biofuel obtained from sludge of wastewater treatment facilities has strong prospects for implementation throughout Russia Federation.

The technology of solid biofuel production is based on removing moisture of wastewater sludge in drying machines. The solid fuel facilities capacity lies in the range of 1 to 130 tons per day, when the entire amount sludge is exposed to drying (effluent humidity of sludge is $10 \%$ ), or 1 to 400 tons per day when the sludge is partially dried and afterwards is mixed with the initial sludge (effluent humidity of sludge is $40 \%$ ). Sludge drying facilities are designed for all-year operation ( $8760 \mathrm{~h}$ per year) and include standard equipment used in the chemical and construction industries. A scheme of drying facilities application at Moscow wastewater treatment plant is shown on fig. 1.

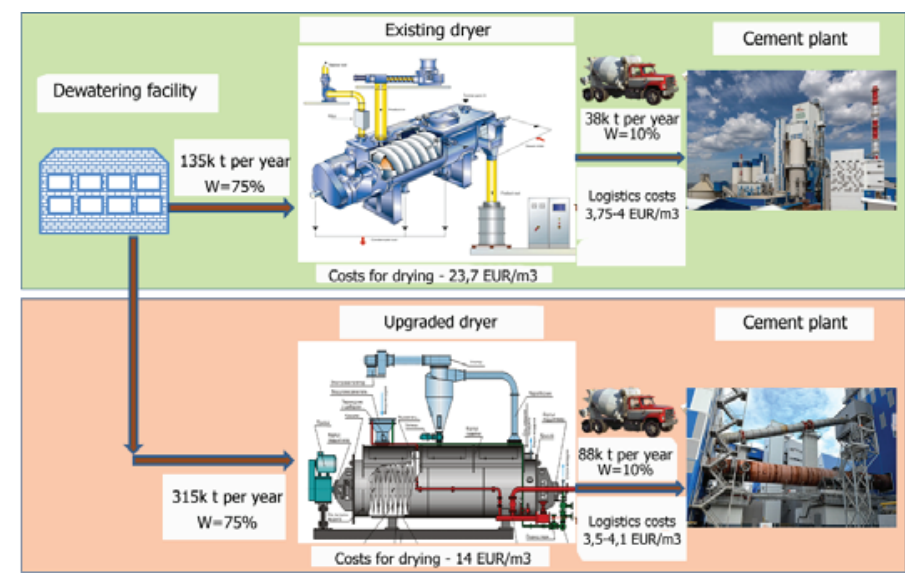

Fig. 1. Perspective use of drying facilities at Moscow wastewater treatment plant

\section{Results}

Process of solid bio-fuel production may include one or more production lines consisting of the following technological equipment:

- Drying machines;

- Mechanisms of transportation of raw materials and finished products;

- Mechanisms of dosing and feeding of raw materials;

- Mixing devices (optional);

- Product unloading and storage device;

- Systems for aspiration and purification of emissions;

- Automation and control system;

- Automation and control system. 
The main characteristics of the WWTP wastewater sludge disposal plant with solid biofuel production are presented in table 1 .

Table 1. Main parameters of solid waste production facility by means of direct drying

\begin{tabular}{|l|c|}
\hline \multicolumn{1}{|c|}{ Parameter } & Value \\
\hline Capacity of the facility (raw sludge with humidity of 75\% ) $\left[\mathrm{t} \mathrm{day}^{-1}\right]$ & $1-130$ \\
\hline Capacity of the facility (as for dried sludge) $\left[\mathrm{t} \mathrm{day}^{-1}\right]$ & $0.7-100$ \\
\hline Weight of the facility [t] & $<25$ \\
\hline Height of the main equipment [m] & $<10$ \\
\hline Area needed [m $\left.{ }^{2}\right]$ & $<30$ \\
\hline Power supply [kW] & $<200$ \\
\hline Voltage [V] & $3 \times 380$ \\
\hline Air consumption (5-7 bar) $\left[\mathrm{m}^{3}\right.$ day $\left.^{-1}\right]$ & 0.5 \\
\hline Steam consumption for dryers $\left(9-11\right.$ bar) $\left[\mathrm{t} \mathrm{day}^{-1}\right]$ & $2-150$ \\
\hline Water consumption for steam generator $\left[\mathrm{t} \mathrm{day}^{-1}\right]$ & $1-10$ \\
\hline
\end{tabular}

Sediments (sludge) of biological treatment facilities of household and mixed sewage after completion of operations on their processing can be used as raw materials for solid biofuel production according to this technology $[6,7]$.

The sludge used in the production of solid biofuel must have an agreed waste passport (confirming the classification of waste to the IV-V hazard class).

It is forbidden to use in the production of solid biological fuel sediment from industrial wastewater treatment plants, mixtures of industrial wastewater and household wastewater, sediment from surface wastewater treatment plants from industrial and residential sites, sediment from local treatment plants of industrial production and storage facilities, repair of road, rail, aviation, sea and river transport

Following types of sludge are forbidden for further drying:

- Industrial wastewater sludge;

- Transport facilities wastewater sludge;

- Energy facilities wastewater sludge.

Table 2. Requirements for incoming sludge

\begin{tabular}{|l|c|}
\hline \multicolumn{1}{|c|}{ Parameter } & Value \\
\hline Foreign inclusions & none \\
\hline Humidity [\%] & $<77$ \\
\hline Ash content [\%] & $<55$ \\
\hline Total carbon [\%] & $>15$ \\
\hline Total hydrogen [\%] & $>2$ \\
\hline Volatile matter yield [\%] & $40-60$ \\
\hline Class of hazard & 4 \\
\hline
\end{tabular}

The main energy carrier of drying equipment is hot steam. The characteristics of the steam used for the dryer are shown in the table 3.

Table 3. Features of stream for drier facility

\begin{tabular}{|c|c|}
\hline Parameter & Value \\
\hline Inlet steam temperature $\left[{ }^{\circ} \mathrm{C}\right]$ & 180 \\
\hline Steam pressure [bar] & 9 \\
\hline $\begin{array}{c}\text { Steam amount (while drying from } 75 \% \text { to } 10 \% \text { ) [kg per } \\
\text { kg of sludge] }\end{array}$ & $1.0-1.3$ \\
\hline
\end{tabular}


When using thermal oil as a coolant, any thermal oil on a mineral or synthetic basis can be used, providing the elasticity of the liquid vapor at a maximum permissible temperature of less than 0.5 bar [8-10].

Fuel natural gas used in the apparatus of the installation complies with current regulation. Power supply is three-phase current with voltage $380 \mathrm{~V}, 50 \mathrm{~Hz}$. Electric power has to be more than $250 \mathrm{~kW}$.

Water consumption for steam generator recharge is 1 to $10 \mathrm{t} \mathrm{day}^{-1}$.

Table 4. Requirements for water for steam production

\begin{tabular}{|c|c|}
\hline Parameter & Value \\
\hline Organoleptic characteristic & colorless, clean, without suspensions and foam \\
\hline $\mathrm{pH}$ at $25^{\circ} \mathrm{C}$ & $>9$ \\
\hline Hardness $\left[\mathrm{mmol} \mathrm{L}^{-1}\right]$ & $<0.02$ \\
\hline Dissolved oxygen $\left[\mathrm{mg} \mathrm{L}^{-1}\right]$ & $<25$ \\
\hline $\mathrm{Fe}\left[\mathrm{mg} \mathrm{L}^{-1}\right]$ & $<0.05$ \\
\hline $\mathrm{Cu}\left[\mathrm{mg} \mathrm{L}^{-1}\right]$ & $<0.01$ \\
\hline Colour in degrees & $<20$ \\
\hline Turbidity $\left[\mathrm{mg} \mathrm{L}^{-1}\right]$ & $<1.5$ \\
\hline $\mathrm{Cl}\left[\mathrm{mg} \mathrm{L}^{-1}\right]$ & $<0.3$ \\
\hline Smell $\left(\mathrm{t}=20^{\circ} \mathrm{C}\right)$ in points & $<2$ \\
\hline Smell $\left(\mathrm{t}=60^{\circ} \mathrm{C}\right)$ in points & $<2$ \\
\hline $\mathrm{NH}_{4}\left[\mathrm{mg} \mathrm{L}^{-1}\right]$ & $<1.9$ \\
\hline $\mathrm{NO}_{2}\left[\mathrm{mg} \mathrm{L}^{-1}\right]$ & $<3$ \\
\hline $\mathrm{NO}_{3}\left[\mathrm{mg} \mathrm{L}^{-1}\right]$ & $<45$ \\
\hline Fluorides $\left[\mathrm{mg} \mathrm{L}^{-1}\right]$ & $<1.5$ \\
\hline Oxidation $\left[\mathrm{mg} \mathrm{L}^{-1}\right]$ & $<5.0$ \\
\hline Chlorides [mg L$\left.{ }^{-1}\right]$ & $<350$ \\
\hline
\end{tabular}

A feed water heater is provided for thermal degassing. The process takes place at an overpressure of $20 \mathrm{kPa}$ and a saturated steam temperature of $105^{\circ} \mathrm{C}$ and is designed to remove harmful gases. The characteristics of solid biofuels obtained from the disposal of WWTP sewage sludge are presented in the table 5.

Table 5. Solid fuel characteristics

\begin{tabular}{|l|c|}
\hline \multicolumn{1}{|c|}{ Parameter } & Value \\
\hline Appearance & Grey powder \\
\hline Unit weight $\left[\mathrm{kg} / \mathrm{m}^{3}\right]$ & $1500-1800$ \\
\hline Humidity, \% & $<40$ \\
\hline Ash content [\%] & $>55$ \\
\hline Lowest calorific value [kcal $/ \mathrm{kg}]$ & $>1000$ \\
\hline Total carbon [\%] & $>15$ \\
\hline Total hydrogen [\%] & $>2$ \\
\hline Volatile matter yield [\%] & $40-60$ \\
\hline
\end{tabular}

Excessive drying of the sludge to a humidity of $10 \%$ is carried out on disk-type dryers (fig.3). From the drying machine, the dried sludge is transferred to silos for storage by means of a screw and bucket conveyor.

Transportation of dried sludge is carried out by means of screw transporters with electric drive. Unloading is carried out through special nozzles (can be installed at any point along the length of the conveyor). 


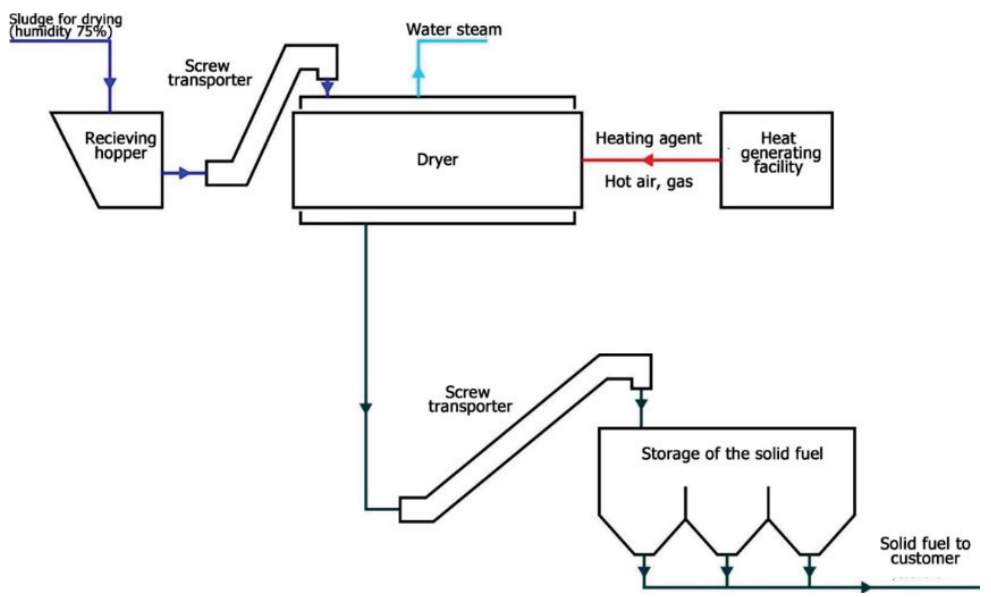

Fig. 2. Scheme of solid biofuel obtaining by means of direct drying to humidity of $10 \%$

During transportation, the dried sludge is cooled to a temperature of $50{ }^{\circ} \mathrm{C}$.

To remove dust from the dry sludge discharge zone, the unit has an aspiration system consisting of:

- exhaust fan capacity $600 \mathrm{~m}^{3} / \mathrm{h}$;

- air filter made in the form of a package of filter cartridges made of polyester fiber installed in a steel housing.

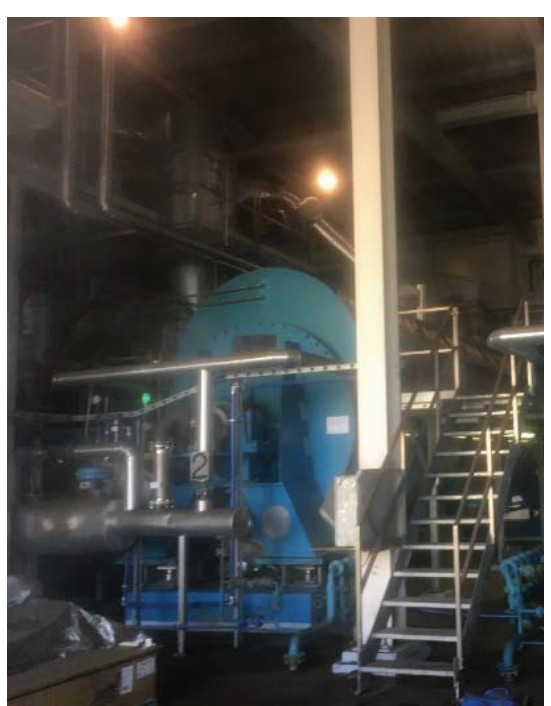

Fig.3 Haarslev driers

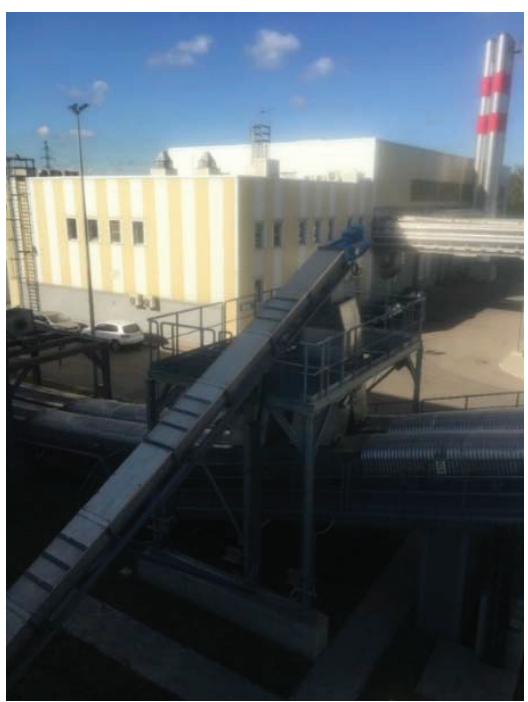

Fig. 4. Dried sludge outlet

Dispensers, where the moisture averaging is carried out, feed the dried sludge with humidity of $10 \%$ from the silo and the initial sludge with humidity of $73-78 \%$ directly to the mixing device.

The process of mixing of sludge with various humidity can occur in a periodic and continuous mode, depending on the type of mixing device.

When using a batch mixer, the process of mixing the mixture lasts 5 minutes, after which the mixture is discharged into the storage hopper, and from there - by screw conveyor to the 
consumer. When using a continuous mixing device, mixing occurs as the mixture advances in the apparatus. The productivity of the process is regulated by changing the supply of sediment from the dispensers. Shipment, as in the previous case, is made from the storage bin. The moisture content of the finished product, corresponding to the brands of solid biofuel, is achieved by the ratio of the dosed components in the mixer.

The required relative humidity of $40 \%$ of biofuels is achieved by mixing precipitation with humidity of $10 \%$ and $75 \%$ in a mass ratio of $1.2: 1$. The plant allows selecting the optimal process of drying of WWTP sludge by temperature, feed rate and other parameters in automatic and / or manual mode. The temperature range of the drying process, adopted at the plant as optimal for both technological schemes, is $150-200^{\circ} \mathrm{C}$. The installation is controlled remotely.

Inertization and fire extinguishing system. Taking into account the risk of explosion, all drying lines are equipped with devices for determining the oxygen content. This device registers the oxygen content and gives a signal to open the nitrogen supply. The nitrogen supply must keep the atmosphere of the dryers inert under all operating conditions. In normal operation, the drying circuit is automatically inert, as the secondary steam of the product provides a very low oxygen content. When starting and stopping, or when starting after a power outage, there may be periods when nitrogen needs to be added to keep oxygen level low.

If in the dryer or cyclone there is a center of decay, which is fixed by the sensors of the $\mathrm{CO}$ level and temperature rise, the fire extinguishing system and water supply are automatically activated to extinguish a possible center of decay

\section{Conclusions}

1. In order to ensure the reliability of treatment facilities and solve the problem of utilization of sediments formed in the process of wastewater treatment, it is necessary to build plants for thermal neutralization of sediments at the wastewater treatment plant of Moscow.

2. The implementation of the project of thermal neutralization of urban wastewater sludge will solve the problem of its utilization and relieve the tension with the search for significant areas of quarries.

3. The volume of recycled sludge will be dropped by more than 6 times, which will reduce the volume of transport and construction works, and, consequently, local environmental impact.

4. The application of the technological cycle for thermal neutralization of sewage sludge expands the possibilities for the use of the resulting ash in various industries (cement, road construction, production of building materials, agriculture and green construction).

5. Production of the heat and electric energy obtained by burning the sludge is a complete technological process.

6. The implementation of projects for thermal sludge neutralization will require an increase in the tariff for water supply and sanitation services at the stage of return on investment.

References

1. S. Ledakowicz, P. Stolarek, A. Malinowski, O. Lepez, Renewable and Sustainable Energy Rev., 104, 319-327 (2019)

2. S. Saxena, Babak Ebrazibakhshayesh, Steven K. Dentel, Daniel K. Cha, Paul T. Imhoff, Sci. of the tot. Env., 672, 927-993 (2019)

3. A. Ronda, M. Della Zassa, G. Gianfelice, I. Iáñez-Rodríguez, P. Canu, Fuel, 247, 148 $159(2019$ 
4. R. Żyłka, W.Dąbrowski, E. Gogina, O.Yancen, J. of Ecol. Eng., 19, 269-275 (2018)

5. N. H. Rodríguez, S.Martínez-Ramírez, M.Teresa Blanco-Varela, S. Donatello, J.Flores, J. of Cleaner Prod., 52, 94-102 (2013)

6. G. O. Uçal, M. Mahyar, M.Tokyay, Constr. and Build. Mater., 164, 178-184 (2018)

7. Z. Chen, C. S. Poon, Constr. and Build. Mater., 154, 791-803 (2017)

8. Z. Pavlík, J. Fořt, M. Záleská, M. Pavlíková, R. Černý, J. of Cleaner Prod., 112, 409-419 (2016)

9. J. Malaiskiene, O. Kizinievic, V. Kizinievic, R. Boris, Constr. and Build. Mater., 172, 553-561 (2018)

10. Y. Zhou, J. Li, J. Lu, C. Cheeseman, C. S. Poon, J. of Cleaner Prod., 118856 (2019) 